\title{
The "Bargain" of Collaboration: African Intermediaries, Indirect Recruitment, and Indigenous Institutions in the Ghanaian Gold Mining Industry, I900-I $906^{*}$
}

\author{
CASSANDRA MARK-THIESEN \\ St Cross College, University of Oxford \\ E-mail: Cassandra.mark@history.ox.ac.uk
}

SumMARY: This article argues that during the formative years of the colonial state in Ghana, European employers established new collaborative mechanisms with African intermediaries for the purpose of expanding the modern mining sector. They were forced to do so on account of severe labour-market limitations, resulting primarily from the slow death of slavery and debt bondage. These intermediaries, or "headmen", were engaged because of their apparent affluence and authority in their home villages, from which they recruited mineworkers. However, allegiances between them and managers in the Tarkwa gold mines considerably slowed the pace towards free labour. Indeed, a system in which managers reinforced economic coercion and repressive relationships of social dependency between Africans, allocating African labour contractors fixed positions of power, resulted from the institutionalization of purportedly traditional processes of labour recruitment into the modern market.

During the "industrialization" of gold mining in colonial Ghana at the turn of the nineteenth century, after two decades of a vexing labour shortage and one disastrous attempt at the large-scale import of indentured labourers from elsewhere in the British Empire, mine managers around Tarkwa finally felt compelled to pull in migrant labourers from various enclaves of West Africa. Modern forms of mining would in future rely strictly on African labourers. Several of these men arrived in the interior

\footnotetext{
* Previous versions of this article were presented at the African Economic History Workshop held on 2-3 May 20I I at the Graduate Institute of International and Development Studies, Geneva, and at the 4th European Conference on African Studies, Uppsala, I 5-I 8 June 20 I I. I would like to thank Jan-Georg Deutsch, Deborah Mason, Alexander Thiesen, and Rouven Kunstmann for their comments. I gratefully acknowledge the Janggen-Pöhn Foundation in Switzerland for research support.
} 
mining district in search of wage jobs from the nearby coastal regions of the colony and its protectorates. Others had travelled from remote villages in Liberia, Nigeria, and Sierra Leone. The Fante, Apollonians, Moshi, Krepi, Wangara, Basa, Kru, Vai, Yoruba, Hausa, Mende, and Timmani were among the social groups turning up in the mining towns.

A considerable number of these young men did not enter modern worksites on an individual contract basis. Rather, they served as members of a gang of roughly twenty-five men, each gang being recruited by and subcontracted to a headman from a shared home village or region. Various scholars have observed that in British West African colonies, the slow death of slavery and debt bondage overlapped with a period of rapid industrialization, often leading to the incorporation of traditional institutions of labour mobilization into large-scale industry. ${ }^{\mathrm{I}}$ Carolyn Brown has demonstrated that to get hold of "free" labour to serve the construction of the railway from Port Harcourt to Enugu in colonial Nigeria during the labour scarcity of World War I, managers frequently went through village authorities for recruits "under the assumption that requests through 'native chiefs' would be accepted by their subjects who, it was alleged, were accustomed to serving their customary labour needs".

This article aims to shed new light on the industrial labour history of Ghana by exploring the system arising from the formal subsumption of such coercive patterns into colonial commodity capitalism during a boom period in the mining industry. It investigates two sets of vertical political relationships. Firstly, those between European mine managers and African workers; and secondly, those between African workers, particularly between headmen and the members of their gangs, engaged in mining for wages as part of their livelihood. The case of indirect recruitment in colonial Ghana demonstrates how, in defiance of an abolitionist rhetoric that put modern commerce on a pedestal, social bondage could be just as

I. For studies on the role of African authorities, in particular chiefs, in labour mobilization for various government services in colonial Ghana, see Kwabena O. Akurang-Parry, "Colonial Forced Labor Policies for Road-Building in Southern Ghana and International Anti-Forced Labor Pressures, I900-I 940", African Economic History, 28 (2000), pp. I-25; idem, “The Loads Are Heavier Than Usual': Forced Labor by Women and Children in the Central Province, Gold Coast (Colonial Ghana), ca.1900-1940", African Economic History, 30 (2002), pp. 3 I-51; idem, "African Agency and Cultural Initiatives in the British Imperial Military and Labor Recruitment Drives in the Gold Coast (Colonial Ghana) During the First World War", African Identities, 4 (2006), pp. 21 3-234; David Killingray, "Labour Mobilization in British Colonial Africa for the War Effort, 1936-46", in idem and Richard Rathbone (eds), Africa and the Second World War (London, 1986), pp. 68-96. After 1906, administrative officials increasingly made direct arrangements with chiefs to recruit labourers from northern Ghana to serve government services and colonial commerce.

2. This was a method known as "political labour" or the "local method"; Carolyn A. Brown, We Were All Slaves: African Miners, Culture, and Resistance at the Enugu Government Colliery (Cape Town, 2003), p. 78. 
constraining following the region's deeper incorporation into the global capitalist market.

In the late I890s, with the backing of the Foreign Office, the colonial government in Ghana embarked on a mission of social and economic development. As in other parts of British West Africa, particular industries were pinpointed and supported in the hope of economic prosperity. Out of this situation mine managers also anticipated that colonial administrators would begin to groom African workers in the ways of the free market. By the turn of the century, the gold mining industry in Tarkwa, previously desperately beseeching the colonial administration for additional support in infrastructure and government services, was now suddenly a core element in the administration's economic agenda. ${ }^{3}$ However, the proliferation of wage labour in commercial companies was evidently taking a unique path. During this period of economic urgency, headmen became a common feature of the labour supply chain in Ghana's mining sector. Not only did these intermediaries recruit labourers, they also moved into the position of ethnic broker, caretaker, and de facto supervisor of the members of their gang for the entire duration of their contract.

In what follows, this article examines the transformation of African authority once it was used for the purpose of industrial labour mobilization. It attempts to discern the changing socio-economic position negotiated by such intermediaries, ambiguously situated between "labour" and "capital", by illuminating their interrelations with the aforementioned groups at various stages of the recruitment process: starting at the point of contact in the village, during the journey towards the mining centre, continuing throughout the contractual period, and even anticipating the extension of relationships between the members of a gang once they had completed a contract, due to shared home ties. The following questions will be addressed. What kind of authority did headmen hold over the larger population of African workers whom they had recruited from a shared home village or region? To what degree was such authority dictated by unwavering loyalty versus complex social negotiations? How did African social relations interact with the beliefs of European managers and officials? Why did managers employ these intermediaries? Moreover, why did European employers not simply fade them out to gain more authority over the labour market?

Methodologically, this study fits into a school of thought that regards European collaboration with indigenous authorities as lying at the heart of imperial policy around the globe. ${ }^{4}$ In Ghana, the expansion of industrialized

3. Raymond E. Dumett, El Dorado in West Africa: The Gold-Mining Frontier, African Labor, and Colonial Capitalism in the Gold Coast, I875-1900 (Athens, OH [etc.], I998), p. 289.

4. Studies exploring collaboration theory in imperial history include: Ronald Robinson, "NonEuropean Foundations of European Imperialism", in Roger Owen and Bob Sutcliffe (eds), Studies in the Theory of Imperialism (London, 1972), pp. I17-I40; idem, "European Imperialism and 
mining fostered, even demanded, new allegiances between Europeans and local authorities. In turn, these new relations also influenced the socio-economic landscape of the expanding wage labour market.

\section{CHANGE AND CONTINUITY IN MIGRANT SOCIAL RELATIONS}

Migration was not a novel feature of the Ghanaian economy. Rather, the story of the twentieth-century mining industry was one of concentrated mass migration. Annually, several thousand labourers streamed from their villages in remote areas of West Africa to find wage jobs in the mines of south-west Ghana. They contributed to an estimated i 5,000 African employees in Tarkwa and Obuasi, a neighbouring mining centre, around the first decade of the twentieth century. ${ }^{5}$ This number included casual piecework labourers, permanently urbanized labourers, and, most of all, subcontract labourers who were bonded by agreement for six to twelve months. They were employed for "surface work which would include cutting firewood, clearing bush, making excavations, moving loads, and in the various underground duties entailed in ore-extraction". 6 Together they comprised a cluster of men of diverse cultural, economic, and regional backgrounds, speaking a multitude of languages.

The list of innovative rituals, relations, and beliefs shaping migrants' identities in the colonial mines of Africa has prompted the research of many scholars. ${ }^{7}$ For Carola Lentz's studies on migrant miners in Tarkwa from northern Ghana, colonial ethnicization has been a driving force of these new politics. ${ }^{8}$ For young male migrant labourers, life in a cosmopolitan area was at once both invigorating and terrifying. Novelty, for example, came in the form of newly acquired liberties and power relative to other

Indigenous Reactions in British West Africa, I880-1914", in H.L. Wesseling (ed.), Expansion and Reaction (Leiden, 1978), pp. I4I-I63; Anthony E. Atmore, "The Extra-European Foundations of British Imperialism: Towards a Reassessment", in C.C. Eldridge (ed.), British Imperialism in the Nineteenth Century (London, I984), pp. I06-125; Jane Burbank and Frederick Cooper, Empires in World History: Power and the Politics of Difference (Oxford, 2010).

5. An annual report from 1908 suggests that the number of African employees in the mining industry "was about I 5,300 of which 540 were European". However, the available statistics are hardly precise; Gold Coast Departmental Report for 1908, National Archives of Ghana in Accra [hereafter, PRAAD], ADM 5/I/I7.

6. Migeod to Governor Rodgers, Semi-Official and Private Letters concerning the Transport Department, no. 661/06, 28 April 1906, Royal Commonwealth Society Library in Cambridge, [hereafter, RCMS], I39/10/3.

7. See for example Patrick Harries, Work, Culture, and Identity: Migrant Laborers in Mozambique and South Africa, c.I860-1910 (London, I994).

8. Carola Lentz, Ethnicity and the Making of History in Northern Ghana (Edinburgh, 2006), pp. I-I 3; idem, "Colonial Constructions and African Initiatives: The History of Ethnicity in Northwestern Ghana”, Ethnos, 65 (2001), pp. 107-1 36. 
social groups. ${ }^{9}$ Lentz demonstrates that in spite of historical tensions and competition, groups from different localities encountered one another on a more or less equal footing in the mining centres. ${ }^{10}$ These "new political structures, rituals and discourses were attractive [...] to migrant workers [...] who sought the same status and respect as colleagues [...] from precolonial kingdoms". ${ }^{\text {II }}$ Among other guarantees, they now received equal pay for equal work and had access to similar legal rights. In conjunction with this shift, she contends that migrant men had simultaneously to establish affiliations to serve and protect self-interest along lines "often containing ethnic overtones, that emphasised ties extending beyond the boundaries of the $[\ldots]$ home village". ${ }^{22}$

Another driving force of colonial ethnicization in the urbanizing centres was the development of new political institutions with an ethnic identity at their centre. These new identities were further normalized through administrative routines led by European officials. Within this ensuing social structure, the headman served as the spokesperson for his ethnic kin. ${ }^{13} \mathrm{He}$ was in charge of negotiations between ethnic groups. In addition, during periods of occupational discontent, he was the one to voice the opinions and grievances of his countrymen. In cases of emergencies, illness, accidents, or death, even in "ordinary small palavers", he stood as their representative. ${ }^{\mathrm{I}}$ At the same time, scholars have pointed out that he was in the service of, and accountable to, the European mine managers. ${ }^{\text {IS }}$

Yet, more than a few studies analysing miners' identities in colonial Africa highlight that they were not dictated by innovation alone, but that older modes of social organization continued to guide the way in which they organized themselves. For instance, D.T. Moodie argues that migrant gold miners on the Witwatersrand imported into modern enterprise a moral order from home. They constructed "new life-worlds out of fragments of the old". ${ }^{6}$ Similarly, William Beinart emphasizes that many

9. Lentz states that in colonial Ghana "ethnicization" within migrant populations paralleled changes within broader society; Lentz, Ethnicity and the Making of History, pp. 2-3.

Iо. Ibid., p. 34 .

I I. Ibid.

I 2. Ibid., p. 2.

13. Carola Lentz and Veit Erlmann, "A Working Class in Formation? Economic Crisis and Strategies of Survival among Dagara Mine Workers in Ghana”, Cabiers d'Études Africaines, 29 (1989), pp. 69-III, 95; Carola Lentz, "The Chief, the Mine Captain and the Politician: Legitimating Power in Northern Ghana", Africa: Journal of the International African Institute, 68 (1998), pp. 46-67, 64.

I4. "Aufargah Mutiny", Letter Book, 9 October 1903, RCMS I 39/4/30.

I s. Lentz and Erlmann, "A Working Class in Formation?", p. 95; Jeff Crisp, The Story of an African Working Class: Ghanaian Miners' Struggles, I870-I980 (London [etc.], I984), pp. 9-10, 76. I6. T. Dunbar Moodie with Vivienne Ndatshe, Going for Gold: Men, Mines, and Migration (Berkeley, CA [etc.], I994), p. 42. 
other groups of migrant workers in South Africa "retained deep roots" that continued to influence identity and self-organization. ${ }^{17}$ The connection to older forms of a socio-political order was not solely abstract either. In her study of industrial coal miners in Nigeria, Carolyn Brown illustrates the persistence of an intimate connection to social hierarchies in the home villages. "Both the state and the industry used men whom they designated as local 'leaders' to control their populations." ${ }^{8}$ Following similar observations in Ghana, Jeff Crisp recorded that, for European employers, "the easiest and most satisfactory way of dealing with Africans" was through African authorities. ${ }^{19}$ Older institutions rooted in the context of a rural environment continued not only to influence migrants' identity and self-organization on a personal level, but also the operative system of labour regulation within modern mining companies.

Still, in the existing literature on Ghana's industrial history there is little mention of social hierarchies among migrants that predated their arrival in these urban areas. The business activities of headmen outside the mines, i.e. their roles as labour recruiters and contractors, are rarely discussed. ${ }^{20}$ The discussion of colonial ethnicization, with its "new forms of classification and self-understanding", ${ }^{21}$ has apparently overshadowed socio-political relationships that may have cut across ethnically homogenous groups in the mines, and that had roots in older power structures and institutions visible across the rainforests, savannas, and deserts of West Africa.

Closely related to the subject of continuities of power structures during the late nineteenth and early twentieth century is, naturally, abolition. ${ }^{22}$ Around this period, the lives of African workers were under two trajectories of major transformation. Firstly, there was the slow death of slavery and debt bondage. The abolition of the legal status of slaves was granted in 1874 . However, following a tradition of scholars who have regarded emancipation

17. William Beinart, "Worker Consciousness, Ethnic Particularism and Nationalism: The Experiences of a South African Migrant, 1930-1960", in Shula Marks and Stanley Trapido (eds), The Politics of Race, Class and Nationalism in Twentieth Century South Africa (London, 1990), pp. 286-309, 305. See also Charles Van Onselen, Chibaro: African Mine Labour in Southern Rhodesia, 1900-1933 (London, 1976).

I8. Brown, We Were All Slaves, p. 97.

19. J. Dickinson, Notes for the Guidance of Europeans in the Gold Coast (Accra, 1939), cited in Crisp, The Story of an African Working Class, p. 69.

20. Lentz and Erlmann mention, but do not elaborate on, the provision of job opportunities for new migrants by headmen; Lentz and Erlmann, “A Working Class in Formation?”, p. I02.

2 I. Lentz, Ethnicity and the Making of History, p. 6.

22. Gareth Austin discusses the limited attention being paid to the subject of abolition in the field of West African economic history in his "Cash Crops and Freedom: Export Agriculture and the Decline of Slavery in Colonial West Africa", International Review of Social History, 54 (2009), pp. I-37, 2. 
as an uneven and slow transformation, Trevor Getz has argued that this "watered-down" piece of legislation "resulted for most slaves only in a gradual re-evaluation of dependent status rather than massive liberations". ${ }^{23}$

Further, Getz advanced the notion that political ties between European colonial officials and African authorities were a crucial motivation to the dilution of emancipatory legislation. During the era of emancipation, colonial administrators were, according to him, acutely aware of their need for the support of African authorities in political and military matters in the colonies. ${ }^{24}$ Thus, just as the reliance of African authorities on the British for military support had quelled violent uprisings in the aftermath of the emancipation proclamation, in turn the British colonial government put forward the pretence of radical transformation in the metropolitan areas whilst maintaining their political allegiances to the same group of African elites for whom slave ownership continued to be integral to wealth, status, and power. ${ }^{25}$

On a perspective that coincides with Getz's in time and concept, Peter Haenger asserts that along with a colonial administration that unsuccessfully attempted to "steer a middle course" in dealing with the issue of slavery, other groups of Europeans in colonial Ghana were equally baffled by the complexities of realizing emancipation. ${ }^{26}$ In particular, he portrays the Basel missionaries as often lacking a straightforward strategy in dealing with the liberation of slaves as they encountered resistance from among their own group of religious followers.

Ronald Robinson, an original voice on the subject of collaborative relationships between Africans and Europeans, has stated explicitly that colonial rule was built upon neither hegemony nor control. More accurately, he declared that it hinged on the establishment of collaborative mechanisms between the British and indigenous peoples. However, economic relationships in Africa, and for that matter also in Asia, were essentially undifferentiated from socio-political ones. ${ }^{27}$ Thus, here, collaboration was not "in the export-import sector but among essentially non-commercial, ruling oligarchies and landholding elites". ${ }^{28}$ Therefore, it

23. Trevor R. Getz, Slavery and Reform in West Africa: Toward Emancipation in NineteenthCentury Senegal and the Gold Coast (Oxford, 2004), p. I60.

24. Ibid., pp. 56, II 3 .

25. Ibid., pp. I I I-I I7. Other colonial governments around Africa took an equally ambiguous stance on ending slavery and debt bondage. For late nineteenth-century East Africa, Deutsch demonstrates that the institution of slavery was hardly challenged, and even supported, by the German colonial government in Tanganyika; Jan-Georg Deutsch, Emancipation without Abolition in German East Africa, c. I884-I9I4 (Oxford, 2006), pp. 97-I44.

26. Peter Haenger, Slaves and Slave Holders on the Gold Coast: Towards an Understanding of Social Bondage in West Africa (Basel, 2000), pp. x, 61-102.

27. Robinson, "Non-European Foundations of European Imperialism”, pp. I29-1 30.

28. Ibid. 
is hardly unusual that with the expansion of the industrial wage labour market, the second major trajectory of transformation, European employers established collaborative relationships with men who they believed already held enough authority to mobilize others. ${ }^{29}$ Given their apparent affluence in their home regions, powerful African intermediaries were hired as labour recruiters and contractors to produce wage labourers for the industrial gold mines around the Tarkwa area.

For the period I900 to I906, it is useful to distinguish between larger political bodies formed mainly according to European design in the context of the mines, i.e. the councils, from smaller groups of socially homogenous gangs whose formation predated their arrival at the mines. To examine social relations within these smaller "gang" units, this article moves beyond the topic of ethnicity to compare the gang system with older institutions for labour mobilization.

\section{RELATIONS BETWEEN "CONTRACT BOYS"30 AND HEADMEN}

Associations between headmen and labourers may have been temporary in a professional sense, but in most cases their personal relationship extended far beyond the setting of the gold mines. Some headmen may have already been in the employment of industrial mines before setting off on the lengthy journey of labour recruitment. Nevertheless, they all initiated the "collection", or "shepherding", of migrant workers in their rural home region. ${ }^{3 \mathrm{I}}$ Though they may have shared similar lifestyles in that environment, by the time a gang reached the urban workplace distinctions between a headman and his labourers were evident and visible even in dress. The headman was in Western clothing: cotton T-shirt, fulllength trousers, and cloth cap so typical of a contemporary industrial worker; ${ }^{32}$ typical "unskilled" workers, in turn, were still sighted in loincloths and traditional cloth garb. ${ }^{33}$ Many of the recruits chosen to engage in the tasks of drudgery and menial labour would have been young men

29. Writing about various types of labour recruiters in India, Tirthankar Roy explains that the ensuing imperfect wage markets "[created] space for individuals already enjoying economic or political power of some kind to try to become monopolistic suppliers"; Tirthankar Roy, "Sardars, Jobbers, Kanganies: The Labour Contractor and Indian Economic History", Modern Asian Studies, 42 (2008), pp. 971-998, 978.

30. For an original usage of this term, see "Inspector General of Police v. Seiden Wangara", July 1918, PRAAD, ADM 27/4/60, pp. 276-277.

3I. These contemporary terms were used to describe the system of indirect recruitment serving the mines.

32. See Figure I.

33. For an image of "unskilled" Liberian and Ghanaian labourers in Ghana around I895-1905, see Dumett, El Dorado, p. 260. 


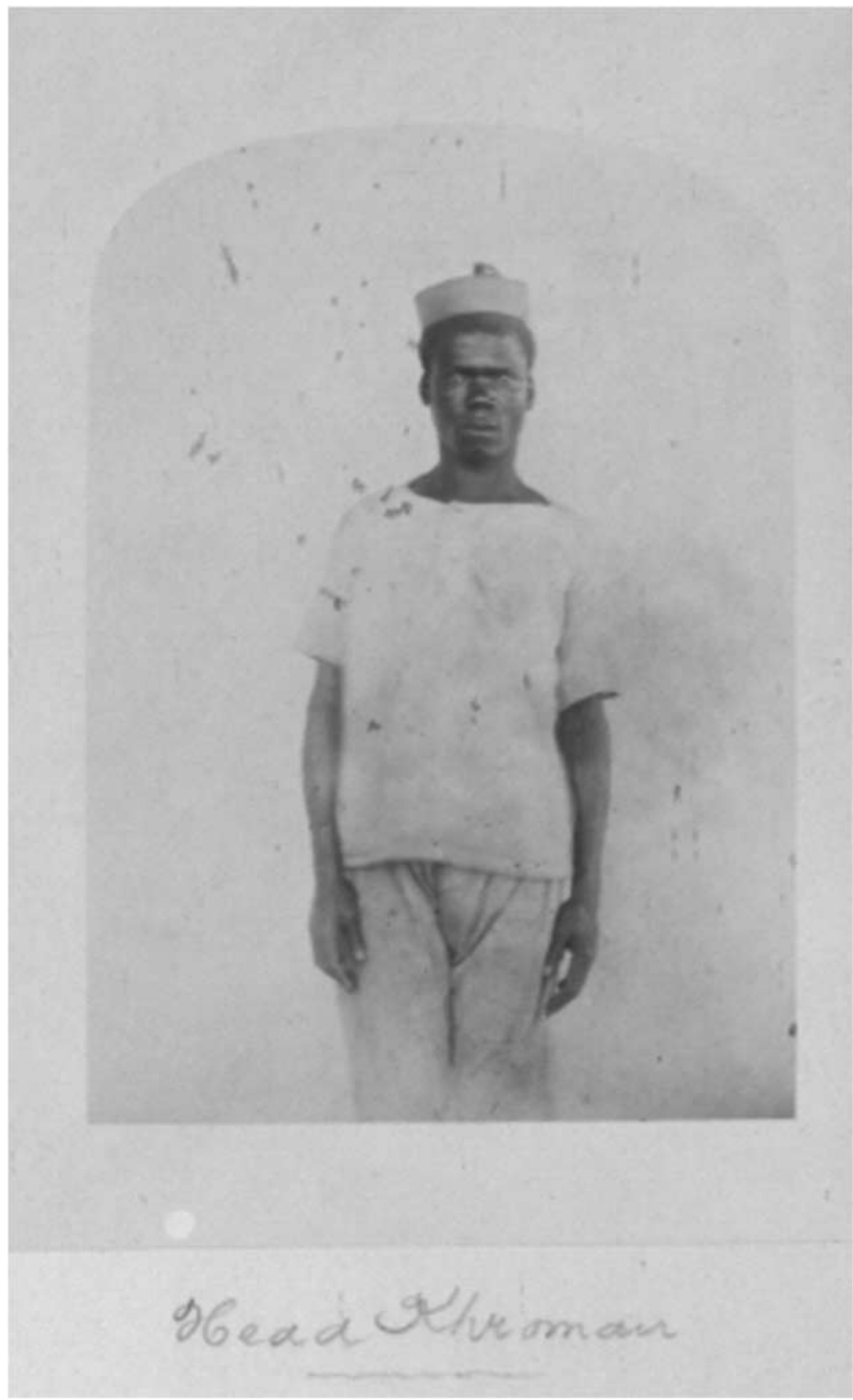

Figure I. Kru headman on the Gold Coast (c.1876-1877).

National Archives of the UK: ref. COI069/29/34. Used with permission. 
belonging to a more socially vulnerable class of the community, or possibly even former or current slaves. ${ }^{34}$

In sum, labourers would likely have felt an obligation to their headman that surpassed modern-day employer-employee relationships. Just as some chiefs regularly managed to call on their followers for communal labour within the corvée system, so too social pressure could be utilized to mobilize industrial workers. ${ }^{35}$ However, European imaginings of submissive African subjects failed to capture this relationship in its full complexity. A headman gained only a small fraction of his authority by virtue of a natural and selfaffirmed affiliation between him and the labourers rooted in home ties. Indeed, indigenous economic institutions that could enforce coercive labour arrangements were far more vital to the amelioration of the pervasive labour scarcity, as seen in the widespread use of credit for the purpose of industrial recruitment.

Polly Hill shows that credit relationships were an integral part of ruralbased economic production and development in parts of West Africa going back to "time immemorial". ${ }^{36}$ Borrowing between farmer-traders was indeed an extension of the social hierarchy. Those individuals who had available surplus became creditors whilst the remaining population became debtors in order to raise starting capital for their enterprises. Such credit relationships were established in many forms, and were settled in an equally diverse number of ways. ${ }^{37}$ For example, one of the patterns by

34. Dumett posits that some of the "generalized" barriers to long-term permanent wage labour for local labourers were even stronger for industrial mining. He gives three key reasons for this aversion, which was rooted in historical socio-cultural beliefs. Firstly, during the nineteenth century it was a taboo for the Akan to mine for gold. Rather, especially for the more dangerous tasks, they employed slaves. Secondly, there was a general awareness that mining was still an extremely dangerous occupation. Thirdly, even during pre-colonial times, the bulk of the workforce in the mines were migrants. These hindrances, along with the fact that no resources had to be exchanged upfront, speak to a higher proportion of local men from the poorest classes of society being extended credit to serve as wage labourers, relative to those who were granted credit for rural-based economic activities; Dumett, El Dorado, pp. I44-I48; Polly Hill, Development Economics on Trial: The Anthropological Case for a Prosecution (Cambridge, 1986), p. 83; idem, The Migrant Cocoa-Farmers of Southern Ghana: A Study in Rural Capitalism (Oxford, 1997), p. I 86.

35. For the pre-colonial period in parts of Ghana, corvée was used for everything from gold mining to agricultural labour and road maintenance; Gareth Austin, Labour, Land, and Capital in Ghana: From Slavery to Free Labour in Asante, I807-1956 (Rochester, NY, 2005), pp. I I 2, I 85-189; Dumett, El Dorado, pp. 7I-72; idem, "Precolonial Gold Mining and the State in the Akan Region: With a Critique of the Terray Hypothesis", Research in Economic Anthropology, 2 (1979), pp. 37-68, 44-47.

36. Hill, Development Economics on Trial, ch. 8.

37. Hill describes some ways in which loans were executed by rural dwellers: through the supply of temporarily borrowed farms, grains for the harvest, short-term loans for trading expeditions, produce to be sold for profit, animals for transportation to trading sites, and the mortgaging of farms to gain starting capital for business activities; Hill, Development Economics on Trial, pp. 89-90. 
which poorer debtors repaid richer creditors was in non-monetary form, as in labour. Hill recognized that, "Grain may be granted to farm labourers who repay, over a period, in terms of work"..$^{8}$

Nonetheless, just as the number of credit relationships increased with commercial expansion, ${ }^{39}$ so did the variety of their manifestations. Relevant here is the adaptation of such credit schemes for urban-based economies during the early colonial period as debtors were routinely recruited as wage labourers for large-scale mining. In order to engage twenty-five men for wage work in the urbanizing areas, it was often necessary for headmen to first loosen their economic constraints in the home villages. Before a gang could depart, it was therefore expected that the labour recruiter would provide each man with an advance payment. These funds were "primarily for the purpose of paying his debts (not for supporting his family) as otherwise his creditors, and natives have creditors, would not allow leave", remarked one European official. ${ }^{4}$ Settling debts with local creditors granted large groups of indebted young men the mobility to pursue work for cash beyond the confinement of their home villages in order to improve their social status, among a broad spectrum of ambitions. Nevertheless, a migrant's debts were never simply written off. This financial exchange was rather equivalent to a switching of patrons.

Assuming the workers' debts, often amounting to several British pounds per individual, was invariably an expensive and risky business. Yet, it allowed the headman-creditor to solidify his authority over the members of his gang. He now possessed the power of economic coercion over them. To be more precise, it served the headman by compelling a recruit to continually sell his labour power in the mines until the debt had been paid off in its entirety. ${ }^{4 \mathrm{I}}$ Since in actuality the terms of lending

38. In addition to labour, repayment could occur in monetary form, or through produce and products; ibid., p. 89.

39. For studies confirming the positive relationships between the availability of "trust", or credit, systems between Europeans and Africans and the spread of commerce in West Africa, see ibid., pp. 89-90; Martin Lynn, Commerce and Economic Change in West Africa: The Palm Oil Trade in the Nineteenth Century (Cambridge, 2002), pp. 67-68; Ray Kea, Settlements, Trade and Politics in the Seventeenth-Century Gold Coast (Baltimore, MD, 1982).

40. "Memorandum on the Concession Labour Bill" enclosed in Confidential dispatch, William B. Griffith to F.W.H. Migeod, No. case 714, 25 March 1904, RCMS I39/i2/i I.

4I. The coercive nature of this system should not undermine the fact that many labourers decided to work voluntarily. Nor should it overshadow the fact that many African workers were driven by more crippling economic pressures. For example, for those men from the border regions of French West African colonies in particular, the pressure to work for wages predominantly stemmed from the poll tax imposed by their colonial government. In spite of efforts by French administrative officials to keep such men within their administrative boundaries as a pool for forced labour, migrants made their way to Ghana, where wages were higher, allowing them to pay their taxes and still have enough money left over to participate in economic activities such as trade; Austin, Labour, Land, and Capital, pp. 40I-402. 
seemed to have largely rested in the headman's hands, he could spread the period of repayment, during which he gradually deducted this sum along with other fees and fines from his men's wages, as he saw fit (but likely with the limitation of a few months). ${ }^{42}$ Although it is uncertain what amount of capital headmen possessed before their service engagement, the prevalence of this form of inducement to labour indicates that, at the very least, when he was in need of cash, mine managers were eager to provide him with enough money to conduct recruitment activities seamlessly. There is further documentation of African employers in the timber industry taking a similar approach to recruit labourers. ${ }^{43}$ In addition to such capital tying labourers to headmen, once they used it to pay off their pre-existing debts, young men incurred additional debts during their journey to the mines.

There is no evidence that in the course of migration any labourers travelled with much, if any, remuneration. Firstly, potentially severe transportation costs, as required by travelling by train in 1903, for example, were initially the headman's responsibility, though they were later deducted from the workers' wages. ${ }^{44}$ Secondly, small rations of fresh produce, grain, and water ${ }^{45}$ were of limited use for what could range from several days to weeks of trekking on foot over hundreds of kilometres, or travelling for several days upon a German steamer, as was usually the case for labourers from Liberia. Therefore, in contrast to the self-financed journey home ${ }^{46}$ during which migrant workers usually had to purchase their own food and water and pay their own fares, ${ }^{47}$ a headman would

42. It was also routine to wait until labourers had reached the mines before assigning them a concrete rate of pay; Migeod to Governor Rodgers, 28 April 1906.

43. "Quow Hammah v. Mahoma Nuhu", Criminal and Civil Record Book, District Commissioner's Court, I894, PRAAD, ADM 27/4/4I, pp. 39-42. Hammah testified: "I live at Abosso and I am a petty trader and I am also a contractor for firewood for the Abosso Company. One the Wednesday last I counted $£_{24}$ [intended to be given] to a man Quamina Amman to take to the coast to advance labourers."

44. For example, one colonial official declared, "the cost of the steamer and the headmoney [for the Liberian government] is usually and properly paid by the employer. Sometimes, however, it is deducted from the men's wages"; Migeod to Governor Rodgers, 28 April 1906.

45. In I9I4, an administrative official reported witnessing many gangs en route to Kumasi. They "are usually conducted by a native who had been to Kumasi before, and their members each carried with them a scanty supply of food and very little else"; Report on the Northern Territories, "Immigration and Emigration", Gold Coast Departmental Report for 1914, PRAAD, ADM $5 / 1 / 23$.

46. Even Kru labourers who were imported by steamboats were responsible for their own return fares.

47. The colonial administration was concerned with the effect that rising food prices would have on the flow of migrant labourers into Ghana. The voyage home could be especially precarious. "During the dry season a soldier on his way to Kumasi on leave from Northern Nigeria informed [the District Commissioner] on his arrival that he had paid no less a sum than $£_{2}$ for water since he had entered the Protectorate at Bawku"; Report on the Northern 
also have been expected to offer the aforementioned provisions in subsistence and travel. Offerings of this kind ensured the labourers' arrival in a good healthy condition. At the very least, gang members had to be strong and energized enough to contribute to the building of their own housing, which they were permitted three days on full pay to complete. ${ }^{48}$ The relationship of dependency that was established with indirect recruitment eventually carried over into the subcontracting period.

Formal sources of credit stemming from European employers eventually became entangled with the financial institutions established between Africans. Before embarking on a single day's work, or even witnessing conditions in the mines first hand, labourers were getting themselves deeper in debt by around 20 shillings. ${ }^{49}$ In this case, the cash was a straightforward economic incentive, and could be spent arbitrarily. Administrative reports noted that men from the urban coastal regions of Ghana found offers of this kind particularly attractive, despite the negative impact on their final wages. It was evident that, " $\mathfrak{E}_{2}$ a month with an advance of $20 /-$ is more desirable than $\mathfrak{£}_{2.10 /-}$ a month with no advance". ${ }^{50}$ Many companies even used competitive advances of up to 30 shillings, far surpassing the i० shillings suggested by the administration, to attract workers. ${ }^{\text {sI }}$ The acceptance of such credit stood as a ratifying seal of approval upon a worker's consent to serve. ${ }^{52}$

Nevertheless, there was a more dubious side to this competition since labour recruiters frequently used these cash advances to induce desertion from competing concessions. This tactic may have been fair game for the recruitment of casual labourers. However, secret talks had to be held with the highly favoured "agreement boys". The ensuing conversation mirrored parts of the negotiation process that would have occurred in the home villages. The covering of debts, future wages, transportation costs, lifestyles on site, and the supply of advances were initial items to be settled out of the earshot of potential informers to local management. ${ }^{53}$

Territories, "Immigration and Emigration", Gold Coast Departmental Report for I9I4, PRAAD, ADM $5 / \mathrm{I} / 23$.

48. Migeod to Governor Rodgers, 28 April 1906.

49. Griffith to Migeod, 25 March 1904.

50. "Concession Labour Ordinance”, Letter Book, Sekondi, 3 December 1903, RCMS I39/4/57.

s. Ibid.

52. Often when a labourer was brought before the court and charged with desertion it was emphasized that he had not only entered into contract with a particular mine, but also that he had accepted an advance of a given amount.

53. For example, during the hearing of one allegedly illicit recruiter, the "underground boy" Albert Kofi testified: "I know Bonsa Kwamin the accused. I knew him a week ago. Accused came to me and asked me if I worked. I told him yes. He said he wanted people to work on timber with him and that they would get plenty of money to pay our debts. Seven of us went with him. He advanced us one pound each. We gave him, accused, a paper for the advance. 
This apparently pricey service was a low cost to bear for mine managers since, as shown above, the wages of those miners who had accepted advances were appropriately adjusted and lowered. However, this calculation panned out only after roughly two to three months of continual work; ultimately employee retention was key. In all this, general management delegated to the headman the difficult and murky undertaking of tracking the multiple balances carried by each of the members of his gang. African authorities, officially insignificant auxiliaries to management, hereby mediated a share of the formal payment structures, another creditbased system.

Mine management may have preferred written contracts under the Master and Servant Ordinance of I893, yet, before 1906, most contracts were still "under hand", 54 and for the length of their six to twelve month contracts mineworkers were subject to extended payment. This meant that they simply did not "draw their pay until the final completion of their contract". 55 In the meantime, similar to older forms of dependency that existed with the institution of nineteenth-century slavery or debt bondage, labourers acquired clothes, small sums of money, and other items by bargaining with their headmen. ${ }^{56}$ This method of extended payments not only strengthened relationships of dependency by temporarily putting the labourers in the seat of "creditor", it also gave mine managers some peace of mind on the issue of retention. In 1903, one administrative official concluded that "a labourer does not desert when he has some money standing in his credit, except the provocation on part of his employer be unendurable; and there being no monthly payment in his case he does not take two or three days off after pay day to enjoy himself".57

Yet, there remained some room for manoeuvre. Rather than depending strictly on allowances from their headmen, some workers managed to

His clerk told us we would not get a full advance from accused. He refused to pay our train here. We asked him to pay what the mine at Tarquah owed us when we left at his request. He complained to the F.M. at Abosso and he sent us all to the police. Accused spoke to me first at Tarquah and said if I left the mine we would get plenty of money on timberwork" ;"Inspector General of Police v. Bonsa Kwamin", Criminal and Civil Record Book, District Commissioner's Court, 1919, PRAAD, ADM 27/4/6I, pp. 223, 25; "Inspector General of Police v. Mana Wangara”, Criminal and Civil Record Book, District Commissioner's Court, I9I4, PRAAD, $\mathrm{ADM} 27 / 4 / 54$, pp. 246-252.

54. "Coolie Labour", House of Commons Papers, Accounts and Papers (1906), pp. I-50, 34. Therefore, Herbert Bryan, the Acting Governor, argued, "labour is seldom 'indentured' in the strict legal interpretation of the word".

55. "Rates of Wages and Cost of Living", Gold Coast Departmental Report for 1904, PRAAD, $\mathrm{ADM} 5 / \mathrm{I} / \mathrm{I} 3$.

56. Akosua A. Perbi, A History of Indigenous Slavery in Ghana: From the Isth to the 19th Century (Accra, 2004), pp. 49-50.

57. "Report on the Transport Department, 1903", Rhodes House Library, Oxford [hereafter, RHO], 7ss.I 4 s.io. 
secure loans from individuals from the Fante coast of Ghana. ${ }^{58}$ This option, nonetheless, proved of limited satisfaction. Labourers commonly became discontented after a six-month period under such constraints. ${ }^{59}$ Having taken these limitations into account, one European employer asserted, "I do not care that they be bound for longer, as much trouble arises in consequence". ${ }^{60}$ Certainly, migrants could find ways to finance a variety of entertainment: gambling, drinking, and sexual relationships. Yet, there existed constant reminders of their bondage.

At the end of a contractual period, when the time came to hand over payment, there also remained, as earlier implied, large scope for abuse since all payments went through the headman. ${ }^{61}$ Referencing labour contractors in South Africa around the late nineteenth and early twentieth centuries, Alan Jeeves has posited that they "preferred this system rather than that where the mine paid the workers directly because it enabled them to discount wages in various surreptitious ways". ${ }^{62}$ In Ghana, some headmen were just as conniving, managing to lengthen their men's service by continuously and strategically raising fines. ${ }^{63}$ In one especially bad case, a particular headman refused payment to his entire gang after several months of hard labour. ${ }^{64}$

These strategies of tying workers for (relatively) short terms were pervasive throughout the recruitment process during the first years of the twentieth century. Supported by collaborative mechanisms between European employers and African headmen for the purpose of labour recruitment, these schemes were not, however, carried out in a facile manner with obedient followers, albeit perceived as "traditional". They required a high level of financial and social management. Nevertheless, indirect recruitment had a counteractive effect on the ambitions of contemporary "agents for change" for free labour. It obscured and weakened such humanitarian efforts since headmen could solidify and enhance their positions relative to the larger population of African workers. Considering that under British protection no individuals were supposed to be working under coercive conditions any longer, and at the very least they were to be

58. In a I910 letter one headman complains about the damaging consequences of his men taking credit from "Fanti” people; Letters from Natives of West Africa, 1904-34, Letter no. 3, Essikadoe, Sekondi, 3 February 1910, RCMS I39/12/52.

59. "Report on the Transport Department, 1903", RHO, p. 472.

6o. Ibid.

6r. Criminal and Civil Record Book, District Commissioner’s Court, i6 April I902, PRAAD, ADM $27 / 4 / 43$, pp. 330-33I.

62. Alan Jeeves, Migrant Labour in South Africa's Mining Economy: The Struggle for the Gold Mines' Labour Supply, I890-I920 (Kingston, ONT, 1985), p. 97.

63. "Tarquah Mining \& Exploration Company v. Kukoboa", Criminal and Civil Record Book, District Commissioner's Court, I8 November 1909, PRAAD, ADM 27/4/48, pp. $762-763$.

64. Ibid., pp. 297-299. 
working by agreement, an investigation launched by the House of Commons into the state of these indentured labourers in 1906 indicates that many Europeans still had major concerns about the virtues of the gang system. ${ }^{65}$ The nature of relationships between members of a gang remained hauntingly ambiguous. So, why did mine managers accept the infusion of "traditional" authority into the labour process?

\section{RELATIONS BETWEEN MINE MANAGERS AND HEADMEN}

In the setting of the formative colonial state, Europeans relied on African employees for a wide range of essential duties. According to Lawrance, Osborn, and Roberts, these were Africans who "held positions that bestowed little official authority, but in practice the occupants of these positions functioned, somewhat paradoxically, as the hidden linchpins of colonial rule". ${ }^{66}$ Europeans hired these men in spite of realizing that African intermediaries would have to tackle the competing interests of serving their professional appointments whilst also satisfying their personal ambitions in the accumulation of power, wealth, and honour. In modern industry too, they faced these challenges. Mine owners in early colonial Ghana therefore had to negotiate their continual dependence on the authority of these individuals for daily functions, with the long-term goal of abolition and the spread of free wage labour.

Language barriers were one obstacle that few European officials, let alone entrepreneurs, had the time or boldness to cross. In the formal setting of the colonial state, such as offices and courts, European employers could rely on educated African middlemen, who sometimes spoke multiple European languages along with indigenous ones. Also in the wide and often tumultuous landscape of the goldmines, managers were incapable of looking over the shoulders of all the men working on a single concession. Difficulties in controlling the often hundreds of workers were multiplied as European mine managers had to deal with a wide range of languages and dialects. Thus, to minimize some of these problems within the organizational hierarchy in the mines, managers required that their headmen spoke at least some English, perhaps just enough to give and take orders. ${ }^{67}$

Keeping track of workers alone was a daunting task for mine managers, who often lacked an overview of the individuals in their employment at a

65. "Coolie Labour", pp. I, 34-35.

66. Benjamin N. Lawrance, Emily Lynn Osborn, and Richard L. Roberts (eds), Intermediaries, Interpreters, and Clerks: African Employees in the Making of Colonial Africa (Madison, WI, 2006), p. 4.

67. Official Correspondence and Papers, Gold Coast Transport Department, 2 December 1904, RCMS I39/ri $/ 8$. 
given time and in a given place. This issue remained infinitely more difficult where the workers were predominantly subcontracted, as opposed to having individual contracts under the Master and Servant Ordinance of I 893. ${ }^{68}$ Individual registrations would have been costly and the colonial government continuously dodged shouldering such a burden. Instead, they pointed to the lack of cooperation between mines as the origin of the continual desertion problem. Administrators were certainly not convinced of the benefits of a fixed class of wage earners. This was, after all, a period in which colonial institutions were already stretched thin. Indeed, they could barely monitor who was entering and leaving the colony throughout the year. As a result, the difficulties of labour supervision grew proportionately with the number of African workers put to work. Given the frequent and widespread turnover in labourers, at least on an annual basis, this problem would not necessarily improve with time. In I905, in neighbouring Asante, for example, a mine manager noticed to his own terror that "there was a much larger number of natives employed [there] than [they] had any idea of owing to the system of contracts whereby only one name appeared on the books". ${ }^{69}$

If European employers were not even clear about who was part of the workforce in their own companies, there was hardly any chance of them exercising adequate supervision themselves. This should not imply that the benefits of more extensive supervision by Europeans over single gang units were not regularly discussed. ${ }^{70}$ Still, the financial burden of implementing such an operation remained unsustainable. The manpower was simply not available at a reasonable cost. In actuality, aside from senior management, white staffers generally also worked on an annual basis in administrative jobs in accounting, or technical jobs such as surveying. Moreover, there were usually only two mine captains under the direction of a chief mine captain. They were the ones in charge of supervising the

68. Around the late nineteenth and early twentieth centuries, some workers from Nigeria and Sierra Leone executed contracts under the Master and Servant Ordinance for roughly six months. However, predominantly Liberian Kru workers were "enlisted in their own country informally, and the agreement [was] properly drawn up under the Master and Servant Ordinance on their arrival in this Colony". This generally obligated them to twelve months of service. Arriving on steamboats at Sekondi, they were much easier to capture and register by local district commissioners before they made their way up to Tarkwa; Migeod to Governor Rodgers, 28 April 1906.

69. "Report by Mr. Mann", Mines Correspondence Inwards, I0 January 1905, London Metropolitan Archives, Ms I4I7I v.I I, pp. 48-54.

70. Migeod asserted that "the value of a gang of labourers varies with the ability of the European in charge. One will condemn a gang as worthless, while another will get most excellent result out of it. Probably under efficient supervision, or if possible working on a fair system of daily task work, a day's work will be performed at will for the expenditure compared favourably with that of an unskilled labour in other countries"; "Report on the Transport Department, I903", p. 472. 
activities of roughly 100 to 200 underground miners, who laboured in the extraction and hauling of ore, as well as surface miners, who worked in the various mills spread across a concession. Reducing the chance of adequate surveillance even further, among the handful of staff at each individual mine there was a frequent rotation of white men having to take to their sickbeds due to the harsh rural environment. ${ }^{71}$ In practice, European supervision in the mining industry was no more than a delicate "thin white line". ${ }^{2}$

As a consequence of the practical limitations of European supervision, during the height of headship, in 1904, it was suggested that to avoid desertions "a native (who would more easily recognize native faces than a European) could be employed, constantly inspecting labourers at the different mines, paying special attention to all newcomers". ${ }^{73}$ Additional lines of inspection by Africans would also have the effect of curbing the illegal activities of African clerks, who were suspected of producing artificial names on the timesheets, and later withdrawing the earnings of these dummy employees. ${ }^{74}$ To this purpose, managers at the Ashanti mine contemplated the employment of four junior clerks. However, by and large, individual headmen administered other African wage earners and stood as their principal barrier to desertion. In fact, when there were runaways, headmen were first in charge of searching for and collecting these absconders. ${ }^{75}$

After carefully examining the devices that mine managers in south-west Ghana utilized to regulate labour migration, Raymond Dumett put forward the view that, contrary to the South African case around that period, they did not manufacture a system of oscillatory migration as a means of influx control. " "Rather they relied on it because it was the only

7I. Dumett claimed that "rotating field management, the inevitable result of illness, frequent rest leaves, and convalescences in Europe, which saddled [mines] with heavy operating costs and destroyed continuity in administration" debilitated mine management in nineteenthcentury Wassa; Dumett, El Dorado, p. 207.

72. Sara Berry, No Condition is Permanent: The Social Dynamics of Agrarian Change in SubSabaran Africa (Madison, WI, I993); Anthony Kirk-Greene, "The Thin White Line: The Size of the British Colonial Service in Africa”, African Affairs, 79 (1980), pp. $25-44$.

73. Griffith to Migeod, 25 March 1904.

74. For example, in the case against John D. Coleman and William Dunn it was alleged that "they on about Feb. 26th [and] April Ist I916 at Abbontiakoon in the Tarquah district did obtain the sum of $£_{I-I 2-I 0}$ [and] $£_{I-I}$ 4-8 from Abbontiakoon by falsely pretending that one Kwaku, a labourer in the Abbontiakoon Mine, worked during the months of February [and] March 1916 whereas [...] in fact he had not worked during those months." Both men pleaded guilty; 6 May 1916, PRAAD, ADM 27/4/56, p. 595 .

75. "Aufargah Mutiny", 9 October 1903.

76. Following Dumett, the narrative of "cheap labour theory" does not fit the case of nineteenth-century colonial Ghana. He has convincingly argued that there is no indication that mine managers deliberately constructed a non-permanent migrant labour force to lower wages and to enhance labour control; Dumett, El Dorado, pp. 224-225, 233. 
alternative". ${ }^{77}$ In reality, the majority of European companies struggled to retain workers, in particular those engaged in underground mining. An irregular labour market "cost them far too much money in lost time and skills and the continuous training of new workers". ${ }^{78}$ In the long term, most workers were not dependent on wage labour for their reproduction, and their freedom to sell their labour power to whomever they desired kept wage rates comparatively high. To make things worse, as mentioned earlier, mining companies failed to cooperate with each other, probably because they had no support from the state when it came to solving the free-rider problem, i.e. in policing agreements among companies. Rather, these entrepreneurs used various shrewd tactics to steal workers from one another, often employing the services of labour recruiters to get men from neighbouring concessions with the attraction of better pay and food. This threat was particularly acute in the first weeks of employment, when workers still had credits to pay off. ${ }^{79}$ Although African workers had mixed incentives to work for wages, a (more) regular workforce was of high priority for most businessmen.

Consequently, during the mining boom in early twentieth-century Ghana, the industry fostered institutions led by headmen that became a pivotal part of managerial strategies. By now it had become noticeably easier for men to enter the wage labour market as a member of a gang, as opposed to on an individual basis. ${ }^{80}$ Naturally, some wage labourers did travel to find work in the gold mines by themselves. ${ }^{8 \mathrm{I}}$ However, given that nobody was sufficiently familiar with them to vouch for them or to supervise and protect them, European employers believed that they were much more likely to abscond from their contracts, leaving behind outstanding debts, and forcing companies to acquire replacements. The gang system aligned smoothly with widespread contemporary European perceptions of "traditional” African culture, which was based on small-scale tribal society. Individual labourers generally fell under the undesirable and suspicious category of "casual labourer". Gangs, by contrast, promised stability and order.

The incorporation of this modified form of "traditional" African authority at once aided early industrialization and made more elusive a comprehensive "market-oriented" approach to economic development

77. Ibid., pp. 269-270.

78. Rumsey (1882) in ibid., p. 270.

79. According to the Chief Officer of the Transport Department, it was "exceptionally rare" for a labourer to desert after several months of work; Letter Book, July-December 1903, RCMS I $39 / 4 / 75$.

80. Uttering his dislike for casual labourers, one administrative official complained: "They stay with an employer so long as it suits them and when the inclination takes them to make a change they merely await pay day to leave"; Migeod to Governor Rodgers, 28 April 1906.

81. Individual workers from Sierra Leone and Nigeria were reputed to travel to Ghana "on their own initiative" to look for jobs; ibid. 
in Ghana. This was because the type of "progress" that was occurring in the mining industry around the early twentieth century modified labour relations in ways that increasingly followed market principles, but also remained based on social incentives. Employers' incorporation of institutions into industry, as opposed to individuals, would perpetuate a growing yet undifferentiated market for wage labourers.

Nevertheless, irrespective of whether they embraced indirect recruitment as a best practice for a tribal society, for most managers around the early I 900 s it was merely a temporary solution which detracted from their long-term objective of better-organized management of wage earners in the colony, with the assistance of state law. ${ }^{82}$ In other words, only as long as radical intervention in the lives of African workers was not a priority of the administration would most businessmen continue to respond crudely to the conditions of the labour market.

\section{CONCLUSION}

The urgent expansion of modern enterprise in Ghana overlapped in time with the slow death of slavery and bonded labour. Yet, the existing literature on industrial labour in Ghana has overlooked the persistence of social hierarchies as it transpired between labourers in modern industry, following the emancipation of slaves. As African colonial employees in the "industrialized" mining sector, headmen initially emerged as labour recruiters and contractors in the Tarkwa region when European mine managers and officials, pressurized by labour shortages during a boom period, were unable to bring large numbers of young men into the labour market with wage incentives. These intermediaries were responsible for recruiting thousands of labourers from within an expansive West African network. Although they would lose influence with time, in the earliest decades of industrialization these types of African authorities enjoyed extraordinary autonomy over the larger population of African workers. In contrast to African colonial employees in government houses, i.e. educated Africans, the headmen derived power from home ties. Mine managers depended on these supposedly "traditional" authorities as they could use their relationships to mobilize other African workers.

It is unclear what percentage of these recruits were slaves. However, modern enterprise certainly adapted to a market wherein African workers

82. The Mine Managers' Association, a collective body of Tarkwa managers founded in 1902, attempted in vain to convince the government to approve the mandatory individual registration of workers in their centres. The Concession Labour Bill sought to curb desertion and other irregularities consistent with the lack of oversight of the workforce at the time; "Concession Labour Ordinance", Press Copy Book, 3 December 1903; RCMS I 39/4/57. See also R.G. Thomas, "Forced Labour in British West Africa: The Case of the Northern Territories of the Gold Coast I906-1927”, Journal of African History, I4 (1973), pp. 79-103, 80, 87. 
were driven by mixed incentives, some of which remained coercive in nature. An even closer look at indirect recruitment and subcontract labour further reveals that African authority, rooted in the home villages, not only remained relevant, but was further strengthened as it was built into managerial strategies. A novel feature of the modern industrial economy, headmen managed to acquire additional personal security and power through the formal and informal structures surrounding the organization in the mines, as they positioned themselves with European employers as natural leaders of "rural" societies.

Indeed, indirect recruitment for the purpose of colonial commodity capitalism mirrored colonial policies of administrative indirect rule in many ways, as social control in the mines was enacted through modified forms of African "customs" and "traditions", whether invented, imagined, or simply practised. Nevertheless, greater emphasis ought to be placed on the recognition that headship was modelled on a system of contested mutual rights and obligations between people as had existed in older times, as opposed to one hinging solely on natural submission. Caretaking and supervision were the rewards for loyalty and hard work. Further, both parties remained in a vulnerable situation due to shifts in debts and finances.

Similarly, the "pulling and tugging" that occurred within the vertical political relationships between European businessmen in colonial Africa and their indigenous intermediaries was certainly not hegemonic. ${ }^{83}$ Some managers may have preferred to use modified forms of pre-industrial productive relations. However, it is unclear whether they could intervene in a radical fashion: whether any amount of investment in the mining industry would have sufficiently affected the contemporary state of the labour force, and, more significantly, the socio-political dynamics defining it. Rather, as a system of new rule, headship seems to have resulted from a pragmatic assessment of the condition of the labour market, where British industrial employers had little other choice.

In south-west Ghana, the "paradox" of allegiances between African intermediaries and European employers was that they simultaneously served to expand colonial commerce and to restrict the growth of free labour. On the one hand, it was the headmen's embeddedness within rural networks, and older types of socio-economic institution, that made them fundamental to industrial labour recruitment. On the other hand, it was the enhancement of their powers within such institutions that made them a threat to radical economic transformation and humanitarian ambitions,

83. In his introduction to Burbank and Cooper, Empires in World History, p. 14, Cooper describes the study of intermediaries as that "of people pushing and tugging on relationships with those above and below them, changing but only sometimes breaking the lines of authority". 
as a considerable segment of the African labour force would remain directly accountable to other Africans, and not to European employers. Social submissions were reproduced. As a consequence, the colonial state would invest much time and effort in regulating indirect recruitment, rather than directly empowering and policing workers. This was the "bargain" of collaboration as manifested in the modern industry of early colonial Ghana. 